Portland State University

PDXScholar

$12-1974$

\title{
Siblings and sex roles: A comparison between male and female graduate students with regard to sibling sex and ordinal position
}

Anita Witt

Portland State University

Follow this and additional works at: https://pdxscholar.library.pdx.edu/open_access_etds

Part of the Social Work Commons

Let us know how access to this document benefits you.

\section{Recommended Citation}

Witt, Anita, "Siblings and sex roles: A comparison between male and female graduate students with regard to sibling sex and ordinal position" (1974). Dissertations and Theses. Paper 2430.

https://doi.org/10.15760/etd.2428

This Thesis is brought to you for free and open access. It has been accepted for inclusion in Dissertations and Theses by an authorized administrator of PDXScholar. For more information, please contact pdxscholar@pdx.edu. 
AN ABSTRACT OF THE THESIS of Anita witt for the Master of Social Work presented December 9, 1974.

Title: Siblings and Sex Roles: A Comparison between Male and Female Graduate Students with Regard to Sibling Sex and Ordinal Position.

APPROVED BY MEMBERS OF THE THESIS COMMTTTEE:

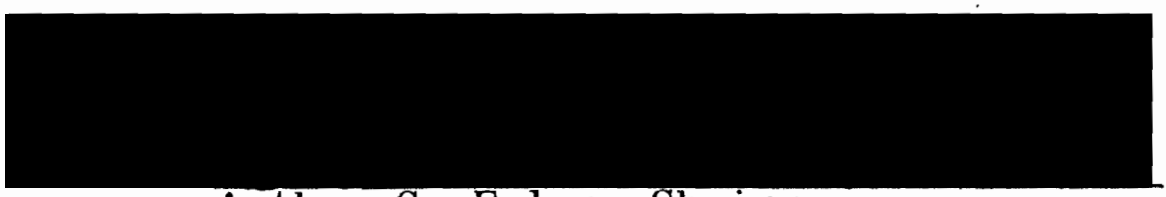

Arthur C. Emlen, Chairman

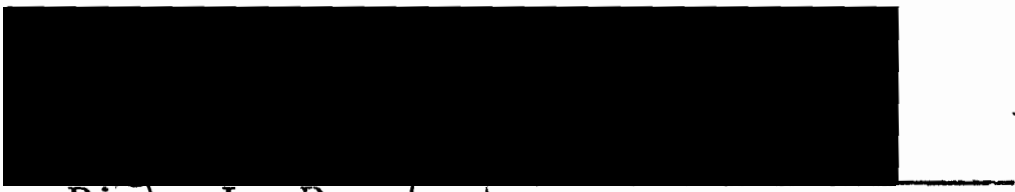

Diahe L. Pancфast

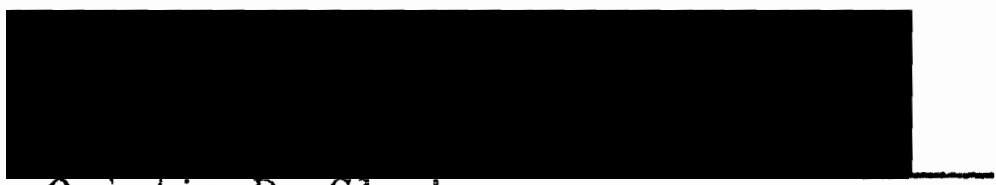

Quentin D. Clarkson

The purpose of the present study was to find out whether there is a relationship between sex role perception, ordinal position, and sex of sibling.

Measuring sex role perception presents a complex problem by itself, since at a time when sex role expectations are changing rapidly, there is little consensus on precisely what constitutes male or female behavior. We were concerned, 
therefore, to avoid as far as possible subjective interpretations of behavior.

We decided to look for a sample of women who had already reached a measure of achievement in a competitive field tradtitionally dominated by men, and who were still available for questioning. Medical and dental students seemed the most appropriate choice. We wanted to know whether these women differed with regard to their sibling positions from their male colleagues on the one hand, and from the students in the School of Social Work, which has been traditionally a more female profession, on the other.

Questionnaires were distributed at the local Schools of Medicine, Dentistry, and Social Work, asking students to identify their positions in their families by indicating sexes and ages of their siblings.

It was found that a significantly greater number of female students are without older siblings than male students. These results appeared both in the medical-dental and in the social work sample. When older siblings were divided by sex, it was found that this relationship is stronger for opposite sex siblings than for same sex siblings.

It was concluded that having older siblings is a handicap for a female wishing to go to graduate school, but not for a male, and that having older brothers is somewhat more of a handicap for her than having older sisters. 


\section{SIBLINGS AND SEX ROLES: \\ A COMPARISON BETWEEN MALE AND FEMALE GRADUATE \\ STUDENTS WITH REGARD TO SIBLING SEX \\ AND ORDINAL POSITION}

by

ANITA WITT

A thesis submitted in partial fulfillment of the requirement for the degree of

\section{MASTER OF SOCIAL WORK}

Portland State University

1974 
TO THE OFFICE OF GRADUATE STUDIES AND RESEARCH:

The members of the Committee approve the thesis of Anita Witt presented December 9, 1974.

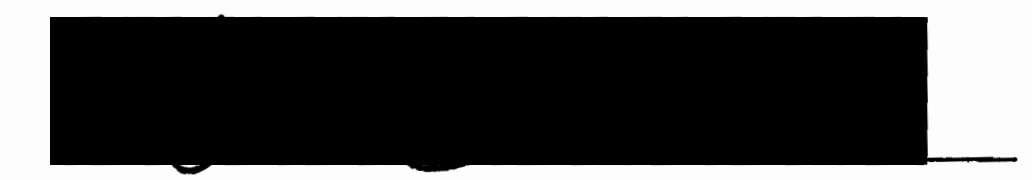

Arthur C. Emlen, Chairman

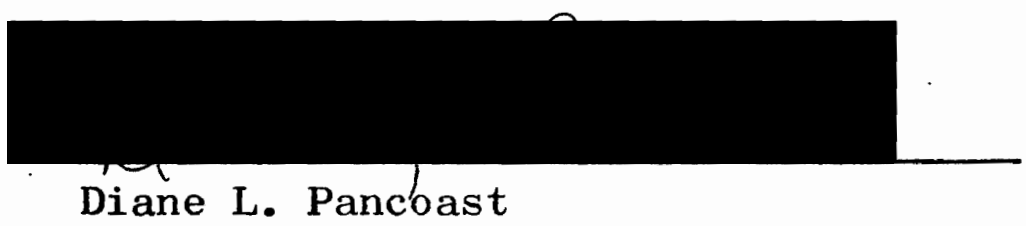

APPROVED:

Quentin D. Clarkson

Gordo Hearn, Dean, School of Social Work

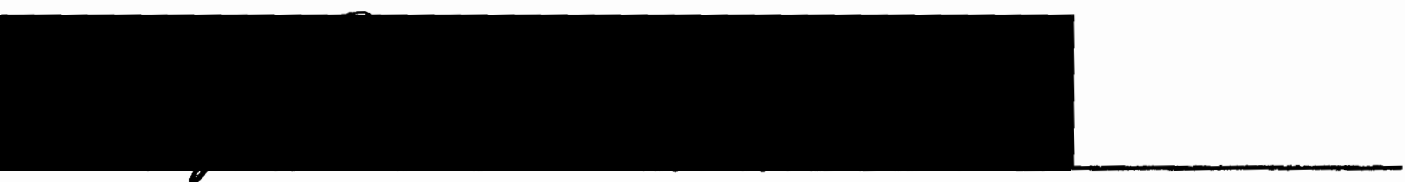

David T. Clark, Dean of Graduate Studies and Research

December 12,1974 


\section{ACKNOWLEDGEMENTS}

I should like to acknowledge my gratitude to $\mathrm{Dr}$. Arthur Emlen, Diane Pancoast, and Dr. Dean Clarkson for contributing their training, knowledge, and experience to this effort. Their valuable advise gave inspiration and direction to this project.

I should also like to express my appreciation to the many students who patiently filled out questionnaires, as well as to the administrators of the various schools who made access to the students possible.

I would like to thank my husband for his patience and support throughout this effort, and our children, for supplying me with many entertaining insights into the politics of the sibship. Last but not least, I should like to thank my sibling, who introduced me at an early age to the fascinating subject of this study. 
TABLE OF CONTENTS

PAGE

ACKNOWLEDGEMENTS . iii

LIST OF TABLES $\ldots \ldots \ldots \ldots \ldots \ldots \ldots \ldots \ldots \ldots \ldots \ldots \ldots \ldots$

CHAPTER

I INTRODUCTION.......................

I. Siblings as an Important Factor

in the Environment of the Growing Child... 1

II. The Need for Changing Roles for

Women......................... 7

III. A Brief Outline of the Methods and

Results of the Present Study...........9

II REVIEW OF PERTINENT LITERATURE.............11

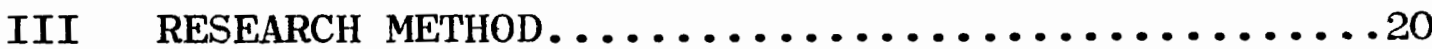

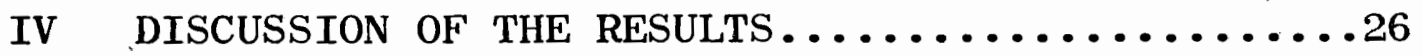

I. A Comparison between Sibling Position of Medical-Dental Students and Social

Work Students....................26 ".

II. A Comparison between Male and Female Students with regard to Sibling Sex......29

III. A Comparison between Male and Female Students with regard to Ordinal Position..34

V IMPLICATIONS FOR SOCIAL WORK PRACTICE.........38

VI SUGGESTIONS FOR FUTURE INQUIRIES . . . . . . . . . 42

VII CONCLUSION.........................

REFERENCES................................ 45 APPENDICES

A TABLES I THROUGH XII.................. 49

B STUDENTS' QUESTIONNAIRE.................62 


\section{LIST OF TABLES}

TABLE

PAGE

I Number of Male or Female Students who have Older Sibling(s) ...................... 50

II Number of Male or Female Students who have Younger Sibling $(s) \ldots \ldots \ldots \ldots \ldots \ldots \ldots \ldots \ldots \ldots \ldots$

III Number of Male or Female Students who have

Sibling $(s) \ldots \ldots \ldots \ldots \ldots \ldots \ldots \ldots \ldots \ldots \ldots \ldots . \ldots . \ldots . \ldots$

IV Number of Male or Female Students who have

Older Same Sex Sibling(s)................. 53

V Number of Male or Female Students who have

Younger Same Sex Sibling(s)............... 54

VI Number of Male or Female Students who have

Older or Younger Same Sex Sibling(s)......... 55

VII Number of Male or Female Students who have

Older Opposite Sex Sibling(s)............. 56

VIII Number of Male or Female Students who have

Younger Opposite Sex Sibling(s) ............ 57

IX Number of Male or Female Students who have

Older or Younger Opposite Sex Sibling(s).......58

$\mathrm{X}$ Number of Male or Female Students who have

Older or Younger Brothers or Sisters......... 59

XI Total number of Brothers or Sisters in Sample... 60

XII Number of Male or Female Students who have

Siblings in One Category only..............61 
CHAPTER I

\section{INTRODUCTION}

Before proceeding with a detailed description of the present study, a brief consideration of the relevant elements is necessary. Hence the following topics will be discussed separately:

I. Siblings as an important factor in the environment of the growing child

II. The need for changing roles for women

III. A brief outline of methods and results of the present study.

An attempt will be made to link the first and second topic to Social Work practice both at the counseling and community organization level. The third topic is included in the indtroduction in order to facilitate the reader's understanding of the literature review.

\section{SIBLINGS AS AN IMPORTANT FACTOR}

IN THE ENVIRONMENT OF THE GROWING CHILD

References to siblings as an important part of the environment of the growing child are rare both in the literature and in classroom discussions of child development. Principal emphasis is placed on the infant's relationship to the parents, particularly the mother. Yet older siblings 
are an existing part of the environment of the newborn infant, and their reception of the new rival is bound to make an impression on the small intruder. Yet no sooner has he made a place for himself as the baby of the family than this place may be challenged again by another arrival. How severely his particular place in the family is threatened may depend not only on the number and interval of siblings, but also on their sex.

Perhaps the lack of emphasis on siblings in psychological literature will be corrected in time. A hundred years ago the obscure legend of Oedipus the King was chiefly remembered because of its dramatization by Sophocles, and without the interpretation of Freud it would have remained a rarely performed play. If we were to search our own mythology for our arch-siblings, we would be confronted by Cain and Abel. Without the illuminating genius of a Sophocles or Freud they are still a fairly obscure pair of brothers, but their story would hardly have survived thousands of years if the listeners had not recognized a portion of themselves in it. This is not to suggest that fratricide is the norm, but rather that each sibling has at one time or another experienced the jealous rage that led Cain to commit the first murder in our mythology.

Most mothers, if they search their memories earnestly, will remember a comment from a toddler who has recently become an older sibling such as "let's take the baby back to the hospital", or "I hate the baby", or "I wish he 
was dead". Rarely are such comments repeated, because the small child learns very quickly that they are not appreciated by the very adults whose approval he craves. The modern mother may not punish such remarks, she merely superimposes her own interpretation "no, you don't hate him; you love him. He's your brother". And there the matter rests, at least for the time being, and the child learns to accept his role as older sib. What happens to his anger is anybody's guess, but sibling research indicates that the child's place in the sibling constellation influences his vision of himself in his future life, and accounts for degrees of competitiveness, aggressiveness, and other traits. Less easily measured but lasting impressions of himself may also originate in the sibling com. munity, a view of being lucky or unlucky, more or less loveable, the "good one" or the "bad one", the "pretty one" or the "smart one". Counselors have been impressed by the number of times clients refer to relationships with siblings, and the extent to which these relationships color life expectations. It might be argued that sibling rivalry is still rivalry over the mother's love, but the same could be said about the Oedipus complex. The mother may well be the object, but the rivalry itself, and how the individual compares himself to his rivals, is of the utmost importance.

In view of the importance of the sibling communi- 
ty it seems reasonable to hypothesize that siblings also exert an influence on the extent to which the growing individual is willing to accept predominant sex role stereotypes. Since sex role stereotyping has been a handicap primarily for females (Mussen, 1969), we concentrated on the question of how siblings affect female sex role perception. We were particularly interested to find out whether a girl with brothers would be more likely to fall into traditional female roles than a girl without male siblings.

The effect of opposite sex siblings on each other could be in either of two directions: sex role neutralizing or sex role reinforcing.

The neutralizing effect might be described as follows: a girl with brothers is exposed to male interests, games, toys, and sports. She may wear some of her brothers' clothes as she grows up, either from necessity or preference. She grows up in an environment where competition with males is taken for granted. Her family may choose recreational activities that are more male oriented than a family with girls only, such as fishing, camping, hunting, ball games. Hence a girl growing up in such a family would be more likely to choose a career that involved competition with males. As will be discussed in detail later, existing research supports this view. Children with male siblings have been found to be more intelligent and achieving than those without male sibs (Koch 1954, Schoonover 1959). Moreover, a neutralizing effect has been demonstrated with regard to 
preferences for toys and games (Koch 1956, Sutton-Smith 1970). However, these observations were made on younger subjects than our sample.

The hypothesis tested in this study was that the effect of opposite sex sibs would be the reverse, i.e. sex role reinforcing. It was speculated that in a family with children of both sexes the father would play baseball or go fishing with his son, but if he had no son, he might accept a daughter as his companion. If there is a son, he would most likely be chosen to satisfy his parents' ambitions for status, he would be urged to get the best education possible, and the family's resources would be put at his disposal for that purpose. Again, without a son, a daughter might be groomed to take that place. If opposite sex sibs reinforce traditional sex roles, we should expect fewer female graduate students to have brothers than male students to have sisters.

Before concluding this introductory discussion of siblings, a historical reflection seems appropriate. Most of the queens in our history books were queens by virtue of not having brothers, had they had male siblings we would barely know their names. Nor has this rule of succession been confined to royalty, but among European craftsmen and farmers the law of primogeniture was also common: it was usually the oldest son who inherited all of the family land or business, which was often at any rate too small to be divided. It was the younger brothers who frequently emigrated to the New. World, and we may speculate that our white 
population is probably largely the offspring of second sons. In the absence of a son the oldest daughter could take over the business or farm by marrying a journeyman of the same trade or a farmer. Throughout her lifetime she would be considered the proprietor, not the son-in-law, who merely provided the necessary skill. Second and later born daughters fared worst of all. They would be the maiden aunts, babysitters par excellence, second wives to widowers, and occasionally shipped off to the New World, too. An available study indicates that second born daughters are the most common inmates of our mental institutions even now. (Schooler 1964) Nor was the effect of siblings status reflected only by patterns of inheritance. DeMause (1974) reports the striking imbalance in the male and female ratio throughout historical records and even prehistorical evidence from grave sites, and concludes that the custom of infanticide favored the survival of male children over female children. Thus he reports a sex ratio of 156 males to 100 females from records of the year 801 A.D., 172 males to 100 females in 1391 A.D., and prehistoric fossil records of 148 males to 100 females. Since the normal ratio at birth is 106 males to 100 females (Kallman, 1952) the alleged prevalence of infanticide in the past may well be a fact. De Mause further reports that the firstborn was usually allowed to live, especially if it was a boy. Thus an infant's very survival may. have depended on the number and sex of his siblings at the time when he or she was born. 
II. THE NEED FOR CHANGING ROLES FOR WOMEN

Until a few years ago, this subject alone would have required lengthy explanations, but since the arrival of the Feminine Mystique (Friedan 1964), the Women's Movement has been so much publicized that more than a few paragraphs would be redundant.

Role differentiation along sex lines is not a modern invention, nor is it necessarily an evil. On the contrary: its origin precedes recorded history and is founded on the biological differentiation of male and female, on the need of the nursing mother and infant for protection, and the necessity for males to band together for the hunt. The very survival of the species has depended on some such division of labor among the sexes, and it seems reasonable to believe that the origin of human society itself is the result of this need to protect and nurture the young. It is not surprising that an institution of such antiquity does not yield easily to a request for change, and it would probably be futile to hope for change if today's sex role differentiation were still firmly based on the original need to assure the survival of the species.

If many women request change today it is precisely for the opposite reason: the division of labor between male and female as it has evolved over thousands of years of civilization is no longer seen as beneficial, but is often felt to be detrimental. Overpopulation and easy methods of birth control have made small families the norm, and labor 
saving devices have reduced housework to a fraction of what it used to be. Attitudes and expectations have changed radically in only a few years. The Women's Movement has emphasized the need for new roles, while many families still look for wives and mothers to fill traditional roles within the home. Anxiety, depression, and conflict in the family are often the result of these pressures (Pincus et al., 1974).

Nor is the strain produced by changing attitudes confined to individuals, but the underutilization of women's talents is a source of national concern, which led President Kennedy to appoint the Commission on the Status of Women in 1961. Oddly enough, in spite of this recognition, the recent trend has been for women. to make fewer contributions. A smaller proportion of college graduates are women than thirty years ago, and only one out of four women capable of college study actually realized this potential in 1964 (Rossi 1964). What is it that keeps women from using all their faculties? Is it possible that part of this question can be answered by looking at the sibling constellation of those women who are utilizing their full intellectual potential?

The Women's Movement has produced some effort to change sex role emphasis in the schools (National Education Association, 1973). Textbooks have been changed to show mothers in other than domestic roles, and sports which were 
formerly closed to girls are beginning to allow girls to compete. However, by the time a child reaches school age he or she has already been socialized along well defined sex roles. Studies of three year olds have indicated that even at that age sex roles are firmly established along traditional stereotypes (Oakley 1972). Nor can it be said that this stereotyping is only a reflection of biological reality, for it has been demonstrated that children can be socialized into the role opposite to their biological sex (Comfort 1965). The overwhelming influence must be looked for in the home environment of the small child. We asked ourselves what, apart from the obvious importance of the parents as sex role models, could contribute to the child's sex role expectation. It was decided to investigate the influence of sibling sex and ordinal position on the development of sex role perception.

III. A BRIEF OUTLINE OF THE METHODS AND RESULTS OF THE PRESENT STUDY

The method chosen to ascertain the possible influence of sibling sex and ordinal position on the development of sex role perception was simple and straightforward.

It was reasoned that in order to get to graduate school, and particularly to medical or dental school, a student must be prepared to enter into competition with many others for a limited number of slots. To get into medical or dental school in particular a female student 
must be prepared to compete with males in a profession that has been traditionally male dominated. We wanted to know whether these women differed with regard to their sibling position from their male colleagues on the one hand, and from the women in the school of social work, which has been traditionally a more female profession, on the other.

We distributed questionnaires at the Dental School, the Medical School, and the School of Social Work, asking students to identify their position in their families by giving us the sexes and ages of their siblings. The results are based on the replies of forty female and forty male students at the Medical and Dental Schools and fifty-four female and fifty-four male students at the School of Social Work.

We found that a significantly greater number of female students are without older sibs than male students. These results are equally true of the medical-dental sample as of the social work sample, and can be seen at a glance in the bottom row of Table $I$. 


\section{CHAPTER II}

\section{REVIEW OF PERTINENT LITERATURE}

Ample research is available on the subject of siblings, and the literature on sex role development is equally abundant, but very little has been written linking the two. What has been done in this area is essentially a by-product of sibling research, where sibling effect on sex role identification is reported among other data regarding sibling relationships.

In view of the great importance that siblings play in the environment of the growing child the ommission of this "sibling factor" in sex role development literature is surprising. Ironically, one exception was found in a recent issue of a women's fashion magazine (Comer 1974) which proclaimed in headline sized letters that female medical students are almost exclusively oldest or only children. This statement coincides to some degree with our own findings and we were interested to find out the source, but inquiries have so far not been answered.

In discussing the literature, the method used by Sutton-Smith and Rosenberg (1970) of identifying individuals will be used here with a slight modification. M will stand for male, $F$ for female, and the individual under discussion will be undeflined. Thus MFF denotes the oldest child, male, with two younger sisters, FM the youngest 
child, male, in an opposite sex dyad. This abbreviation only indicates sex and ordinal position, it does not indicate age spacing.

One of the reasons why the "sibling factor" is so little mentioned outside the field of sibling research itself may be that it is so complicated, and the findings often contradictory and confusing. When one considers that even in the two child family there are eight possible individual positions, and in the three child family 48, the complexity of larger families, especially when age spacing is added as a factor, becomes almost overwhelming. Thus the 24 three-child family positions, as listed by Sutton-Smith and Rosenberg (1970) for males are:

MMM, MMF, MFM, MFF
$\overline{M M M}, \overline{M M F}, \overline{F M M}, \overline{F M F}$
MMM, MFM, FMM, FFM

and for females:

FFF，FMF，FFM，FMM

$\overline{\mathrm{FFF}}, \overline{\mathrm{F} F M}, \overline{\mathrm{M} F F}, \overline{\mathrm{M}} \mathrm{FM}$

$F \bar{F} \underline{F}, \overline{M F}, M \bar{F} \underline{F}, M \overline{M F}$.

Sutton-Smith and Rosenberg (1970) have reduced this complexity somewhat by concentrating on the sibling dyad, with the justification that (1) two child families are much more common than those with more than two children, and (2) even in larger families sibling relationships can be broken down into individual dyadic relationships.

The importance of treating the sexes separately was emphasized by Edward Sampson (1965) who observed in his review of existing research the striking resemblance of 
the first-born male (MF) to the second-born female (MF) and the first-born female (FM) to the second-born male (FM) in the opposite sex dyad. Thus a simple combination of all firstborns regardless of sex, and all second and later borns regardless of sex would tend to obliterate the possibility of finding any significant trend among these groups. The importance of correlating all pertinent factors, ordinal position, sibling sex, and subject sex, had been reported by Sampson already in an earlier study (1962) and was reinforced by a study by Singer (1964) correlating sex and ordinal position to "Machiavellianism" and grade point average. Singer also suggests that the smond-born male and firstborn female are similar in their skillful manipulative abilities, while the first male and seond female are equally unskilled. Although these findings refer to style of interaction rather than achievement, they are corsistent with, and possibly explanatory of, the findings in the present study regarding firstborn females. Firstborn females are significantly overrepresented in our sample of graduate students (Table I), but being a' firstborn male does not appear to be any advantage in achieving graduate status. According to studies by Koch (1954) and Schoonover (1959) neither subject sex nor ordinal position, taken by themselves, relate signifcantly to intelligence. However, both studies have indicated separately that the sex of the sibling is an important determinant of an individual's intelligence. In a study of five and six year olds Koch 
(1954) found that those with a male sib scored higher on verbal tests than those with female sibs. The thoroughness of her study is too impressive to take her results lightly. She used 384 six year olds matched for socio-economic background, residence, and age. There were 48 subjects for each of her eight two child positions. Each of these groups was subdivided into three groups according to the age difference between the sibs, e.g. 0-2 years, 2-4 years, and 4-6 years. Similar spacings have been used in the present studies, but our sample was much smaller, and subjects were counted regardless of family size.

Schoonover's study (1959) confirmed the finding that male siblings raised the subject's score regardless of the sex of the subject. Her sample was drawn from sibling pairs at the University Elementary School at the University of Michigan. While this study revealed a correlation between intelligence and sex of sib, it showed no correlation between either intelligence or achievement and birth order. These findings are opposite to those of the present study, where sibling sex appeared to be insignificant, but ordinal position was found to be related to achievement. This raises an interesting question. Koch and Schoonover's research involved children, and their findings could be said to reveal a potential, but whether or not the potential is realized can only be seen in the adult. Our sample of graduate students is much closer to this realization. What happens in the intervening years that makes sibling sex significant in 
children, and ordinal position in the adult, as an indicator of achievement?

Studies linking sibling sex to sex role preference show conflicting results. Schmuck (1963) reports that girls with a sister more often have tendencies to defy than girls with a brother. He used college age female subjects from two child families, and sibling sex was the only significant variable. In order to measure tendency to defy pictures were used, involving orderliness vs. disorderliness, compliant vs. defiant attitudes, etc., and the subjects were asked to write stories to explain the pictures.

Schmuck's (1963) results are opposite to those of Sutton-Smith and Rosenberg (1970) who found in a study of the effect of sibling sex on sex role preference, using choice of games, that at the preadolescent and college level sex role preference is reinforced among two child families with both sibs of the same sex., i.e. girls with sisters have significantly higher femininity scores than girls with brothers, and boys with brothers score higher on masculinity than boys with sisters. However, it was found that in three child families the effect was different. Boys with two sisters scored higher on the masculinity scale than on the femininity scale as had been expected. It was concluded that males with "too much feminine influence" may have been resisting or counteracting it. Both of these studies emphasize again the complexity of sibling studies, and the inherent limitation of looking only at the sibling dyad. 
An interesting finding was reported by Charles Harrington (1970) in his study of errors in sex role behavior. Boys with excessively feminine behavior were found to have more often older brothers and fathers present in the home than those with more masculine behavior. The author suggests that each family may have a component of male roles which must be filled, and these roles may be expected to be filled by the older males of the household. The boy whose behavior is labelled sex-role inappropriate is a late comer to the family scene and may try, therefore, to fill the feminine role, perhaps in an effort to differentiate himself from his older male' siblings. Harrington's results are supported by Money (1970) who reports sex-ratio studies where the male: female ratio in the sibship of male homosexuals was compared with the expected ratio of 106:100 (Lang 1940, Darke 1948, Kallmann 1952, Slater 1958). Each study turned up a different ratio, ranging from 106:100 in Darke's small sample to 125:100 in Kallman's twin study. The author concludes that the results may reflect a tendency for homosexual men to have more brothers in the family than expected, and that these findings may signify a tendency for an effeminate gender identity to develop more easily in boys whose families have a shortage of sisters. It is interesting to note that Slater (1958) found the opposite to be true in families of male exhibitionists, i.e. a brother:sister ratio of 109:144. With respect to ordinal position of homosexuals, Martensen-Larsen (1957) reports not only a preponderance of brothers over sisters, 
but also a predominance of ordinal positions in the lowest third of the sibship in his sample of 63 homosexuals. The effect of sibling sex alone and separate from ordinal position can only be observed among opposite sex twins. This is one of the subjects investigated by Koch (1966) in her book on twins. She found the males in opposite sex pairs to be less than normally active for males, less emotional and explosive, less exhibitionistic, loud and selfiish than boys in same sex fraternal pairs. Koch interprets this slight tendency toward a more feminine type of behavior on the part of twin boys with a female twin to be the result of the boy's effort to do what is approved. Those findings which have a direct bearing on the present study are of course of particular interest. Both Sutton-Smith (1970) and Koch (1954) describe the first_ born female of the female dyad (FF) as particularly competent. The first-born female of the opposite sex dyad (FM) is pictured as curious, original, enthusiastic, but also high on jealousy, competitiveness, and aggressiveness. She is noted for her leadership. Sutton-Smith and Rosenberg further report that girls who are only children tend to be more masculine than other females. Abernethy (1940) reported in a sample of female college students that firstborns were more aggressive than subjects having older siblings, particularly in families of four or more. Sampson (1962) reported that the firstborn had a higher need for achieve- 
ment than the later born, especially among females. Sampson interpreted these findings as meaning that the firstborn female is more involved than the firstborn male in role behaviors that demand independence and responsibility. These findings are consistent with the present study which found a signifcantly greater number of female than male graduate students without older siblings (Table I). However, these findings regarding firstborns are not without contradictions. Pauline Sears (1951) reports in a study of doll play aggression that both the first male and the first female were less aggressive than younger children. These contradictions regarding aggressiveness of firstborns may be a reflection of the different methods that were used by the researchers, doll play aggression on the one hand, and interpersonal aggression among peers in the classroom on the other. Perhaps firstborns reveal less aggression in doll play because it is too reminiscent of the younger sibling, and aggression in that direction has been too thoroughly repressed.

Koch reported (1955) that the MF was rated low in aggressiveness. This finding is consistent with the earlier reported similarity between the $\underline{M}$ and the $M F$, it is also consistent with our findings. Schachter, in his article on birth order, eminence, and higher education (1963) interprets his findings that more firsborns achieve graduate status as a reflection of the lower birthrate among those of higher socio-economic status, which would result in a high proportion of firstborns among high status occupations. This 
explanation may be correct as far as it goes, but it fails to explain our finding that significantly more female than male graduate students in social work and medicine are firstborns.

In spite of the many contradictions, some trends have developed in the literature. Studies of sibling dyads have shown with some consistency that the oldest female differs from the oldest male and from the youngest female. The firstborn is reported to be a skillful manipulator, competitive, curious, jealous, and aggressive, and more so than either younger sisters or firstborn brothers. All these traits would make her a likely candidate to achieve graduate status. 


\section{CHAPTER III}

\section{RESEARCH METHOD}

In order to assess the effect of sibling sex and ordinal position on sex role identification a number of methods were possible. Measuring sex role identification by itself is a complex problem, since at a time when role expectations are changing rapidly there is little consensus on precisely what constitutes male or female behavior. We were concerned, therefore, to avoid as far as possible subjective interpretations of behavior.

We decided to look for a sample of women who had already reached a measure of achievement in a competitive field traditionally dominated by men, and who were still available for questioning. Medical and dental students seemed an obvious choice. At the University of Oregon Medical School 50 iout of 422 students are women, at the Dental School only 8 out of 344 . If we knew the sibling status of these women, and compared it to male students in the same school, we would then have some idea whether sibling status affected males and females differently in the pursuit of a competitive profession. The registrars at these schools were cooprative in granting us access to students mailboxes and supplying us with lists in order to be able to distribute questionnaires. 
The current achievement status of these students was sufficiently established by virtue of their having been accepted at the medical and dental schools, the only thing left was to ask the sex and ages of their siblings. Oddly enough, even such a simple and factual questionnaire (see appendix for sample) encountered some resistance. We polled all women at both schools, and an equal number of men chosen at random. The women seemed more reluctant and slower in returning their questionnaires, possibly because they have been the subjects of a number of studies recently and are simply tired of intrusions, and possibly because having achieved some success against considerable odds they resent the implication that their achievement was the result of anything but their own efforts and competence.

The purpose of the questionnaire was explained briefly, and a letter urging cooperation was posted on the bulletin boards of the mail rooms in both schools. After questionnaires had been distributed three times, 33 out of the 50 female medical school students responded and 7 out of 8 female dental students. An equal number of questionnaires from male students was obtained, so that the total medicaldental sample was 40 females and 40 males.

If medicine and dentistry have been fields dominated by men, social work has been traditionally open to women. It was decided to poll the students at the school of Social Work in order to see whether they differed with respect to sibling composition from the medical-dental students. In 
the School of Social Work the 1973-1974 graduate enrollment was 59 males and 89 females. All men were polled, and an equal number of women chosen at random. However, it was decided to set an upper age limit of 36 years on the social work students, since in that field there are a number of returning students, all but one female, who are choosing social work as a second carieer after raising a family. The social work students were no more enthusiastic about filling out questionnaires, however, through proximity and availability of their telephone number its was possible to obtain returns on all our questionnaires. The final sample from the School of Social Work was 54 men and 54 women.

We anticipated some difficulty in deciding whether or not to count deceased sibs, but the difficulty resolved itself. Most of the deceased sibs were reported among the over 36 year old group of social work students whose questionnaires were ultimately discarded because of the age factor. There was only one other example; as the sib had died at the time when his brother was already a medical student, he was conted among the siblings.

Results are shown in tables I through XII in the Appendix. Table I, for instance, shows the number of individal male and female students who have older siblings of either sex. The medical-dental sample is counted separately from the social work sample. 
Table II shows individual male and female students who have younger siblings of either sex, Table III those individual students who have either older or younger siblings of either sex. Thus on Table III, the bottom row indicates that those who"have not" are only children. Tables IV through VI count individuals with same sex. sibs, Tables VII through IX individuals with opposite sex sibs. It must be rememered that these counts do not represent the number of siblings, but the number of individual students, male or female, who have or have not either older or younger, male or female siblings. The figures shown in Tables $I$ through $X$ would thus be the same whether a student had one older brother or five, and so on. It should also be noted that in Tables I through $\mathrm{X}$ the same individual may be counted repeatedly. Thus a student having both older brothers and older sisters would be counted as having older same sex and older opposite sex sibs, if he also had younger brothers and sisters he would appear on -all separate tables. Moreover, if he had, let's say, one older brother less than two years older, he would not only appear on Table $I$ as having an older sibling, on Table III as having a younger or older sibling, on Table IV as having an older same sex sibling, and on Table VI as having a younger or older same sex sibling, but he would also appear in each row of these tables, since a sibling less than two years older is also a sibling less 
than four years older, and so on.

However, while the number of older brothers, for example, as such, is not shown in Table I through $X$, it is represented indirectly through age spacing. Again, looking at older brothers, Table IV shows in the upper right that 7 male medical-dental students have brothers up to two years older. Moving one row down, we find that 19. students in the same group have brothers up to four years older, 22 have brothers up to six years older, and 25 have older brothers without age limit. Since the up to two year difference is absorbed by the up to four year difference, and so on, we can conclude that the figure on the bottom, representing individuals with older same sex siblings of any age, also includes more older siblings than that on the top, which only counts sibs up to two years older. A more detailed evaluation of sibling number would go beyond the scope of this study. However, the raw figures are given in Table XI.

Table XII shows numbers of individuals who have siblings in certain groups in mutually exlusive categories. In this table each individual student in our sample is shown only once, in one category. Broken down in this fashion the numbers in each category are small, and a much larger sample would be needed to obtain significant results.

The principal information we hoped to obtain from our data was whether or not male and female students were 
different with regard to sibling composition. Initially, our main interest was sibling sex, but ordinal position emerged as a striking factor. We also expected some differences not only between male and female students, but between medicaldental and social work students. This expectation proved largely unfounded, and some of the possible reasons for this fact will be discussed in the results. 


\section{CHAPTER IV}

\section{DISCUSSION OF THE RESULTS}

Our principal interest has been to discover whether there is a difference in either ordinal position or sibling sex between male and female graduate students in the fiel of social work and medicine/dentistry. Results are summarized in Tables I through XII in the Appendix, and will be discussed here under the following topics:

I. A comparison between sibling composition of medicaldental students and social work students

II. A comparison between male and female students with regard to sibling sex

III. A comparison between male and female students with regard to ordinal position.

\section{A COMPARISON BETWEEN SIBLING COMPOSITION OF} MEDICAL-DENTAL STUDENTS AND SOCIAL WORK STUDENTS

Medical-dental students were chosen as a suitable sample for this study because it was felt that female students entering these fields had to overcome a traditional sex bias. Social work students, on the other hand, would provide a good comparative sample, since social work has always been open to women. With one exception, the results show no significant difference with regard to sibling composition between the two groups of students, and that exception 
appears only on Tabe XII, where it appears that much fewer females in the medical-dental sample have older brothers only than in the social work sample (below). Only one female

Students who have older brothers only

\begin{tabular}{|c|c|c|c|c|}
\hline \multicolumn{2}{|c|}{ SOC. WORK SCHOOL } & \multicolumn{2}{c|}{ MED. -DENT . SCHOOL } \\
\hline $\mathrm{M}$ & $\mathrm{F}$ & $\mathrm{M}$ & $\mathrm{F}$ \\
\hline 5 & 5 & 7 & 1 \\
$\mathrm{~N}=$ & 54 & 54 & 40 & 40 \\
\hline
\end{tabular}

students in the medical-dental sample (2.5\%) compared to five female students in the social work sample (9.6\%) are shown in this category. However, as was mentioned earlier, a much larger sample would be desirable when students are counted in mutually exclusive categories.

Except as shown above, whenever a trend was found in one group, it was also apparent in the other, although not always to the same degree. Obviously, we had to revise some of our thinking regarding the student bodies of these different schools. Their similarities appeared to be greater than their differeñces.

Both are groups of graduate students. In that sense, women students in both areas have had to overcome some sex bias, not with regard to their particular field necessarily, but in pursuing a professional career at all. Furthermore, while the Medical and Dental Schools have made it difficult in the 
past for women to get accepted, the Schools of Social Work have never excluded men. A better group for purposes of comparison with the medical students might have been women. who had not chosen a career at all, or ore that required no competition with men even at the undergraduate level. Housewives and mothers, secretaries, beauty operators, and possibly nurses might have been a better choice. How ever, the difficulty of finding a sample from the same socio-economic background as the medical-dental students in this non-professional group would be difficult to solve. For our study it was decided to add the samples of both groups and thirk of them as graduate students in different fields.

As was pointed out earlier, Tables I through $\mathrm{X}$ show individuals who have or have not siblings of the same, opposite, or either sex. Only Table XI shows the total number of siblings in our sample. It would go beyond the scope of this study, and beyond the size of our sample, to subdivide into groups of individuals with one brother, two brothers, three brothers, and so on. However, a comparison of family size was simple and may be of some interest. It appears that in all schools the females came from slightly smaller families (page 2 9 ). This may reflect the fact that a smaller family is more willing to invest in a professional education for a daughter than a larger family, or it may mean that the women students came from 
from families with a higher socio-economic status and lower birthrates (Schachter 1963). It also emerged that the students from the School of Social Work came from slightly larger families than those of the Medical-Dental. Schools. Again, reflections are similar, this may indicate that a smaller family is more willing to consider the more expensive medical or dental training for their child than a larger family would be, or it may indicate something about the socio-economic status and birthrates of the two groups of students. The figures are as follows:

\begin{tabular}{l|c|c|c|c|c|c} 
School & $\begin{array}{c}\text { Student } \\
\text { Sex }\end{array}$ & $\begin{array}{c}\text { Number of } \\
\text { Brothers }\end{array}$ & $\begin{array}{c}\text { Number of } \\
\text { Sisters }\end{array}$ & $\begin{array}{c}\text { Number of } \\
\text { Siblings }\end{array}$ & $\begin{array}{c}\text { Family } \\
\text { Size }\end{array}$ & N \\
\hline S.W. & F & 64 & 47 & 111 & 3.06 & 54 \\
S.W. & M & 54 & 68 & 122 & 3.26 & 54 \\
M-D & F & 37 & 41 & $78 \vdots$ & 2.95 & 40 \\
M-D & M & 42 & 42 & 84 & 3.10 & 40 \\
\hline
\end{tabular}

\section{A COMPARISON BETWEEN MALE AND FEMALE} STUDENTS WITH REGARD TO SIBLING SEX

One of the questions we asked ourselves when we began this study was whether having male siblings was an advantage or a liablity for a girl wanting to enter a competitive professional career. Data on opposite sex sibs are shown 
in detail in Tables VII through IX. The most pertinent data of Table VII are summarized below, where it becomes apparent that fewer female students have older opposite sex siblings

\begin{tabular}{l|c|c|c}
\hline School & $\begin{array}{c}\text { Sex of } \\
\text { Student }\end{array}$ & $\begin{array}{c}\text { Number of Individuals having older } \\
\text { opposite sex sibling }(\mathrm{s})\end{array}$ & $\mathrm{N}$ \\
\hline M-D & M & 15 & 40 \\
M-D & F & 8 & 40 \\
S.W. & M & 22 & 54 \\
S.W. & F & 16 & 54 \\
\hline
\end{tabular}

than male students. This trend is more apparent among the medical-dental than among the social work students, but exists in both groups. It may be concluded, therefore, that having an older brother is a disadvantage to a female wishing to enter a professional career. However, a comparison between Table IV and Table VII indicates that while having an older brother is more of a handicap than having an older sister, the trend is the same, thus the disadvantage may lie partly with the siblings' ordinal position.

With regard to younger opposite sex siblings, a curious contradiction occurs depending on the method used in counting siblings. On Table VIII no trend appears at all. On this table individuals were counted who had younger opposite sex siblings, regardless of whether they also had siblings 
in other categories. However, on Table XII, we find strikingly more female than male students who have younger brothers only (below). It would appear, therefore, that having a

\begin{tabular}{|c|c|c|c|c|c|}
\hline \multirow{3}{*}{$\begin{array}{l}\text { Students } \\
\text { having } \\
\text { younger } \\
\text { brothers } \\
\text { only }\end{array}$} & & \multicolumn{2}{|c|}{ SOC. WORK SCHOOL } & \multicolumn{2}{|c|}{ MED.-DENT . SCHOOL } \\
\hline & & $\mathrm{M}$ & $\mathrm{F}$ & $\mathbf{M}$ & $\mathrm{F}$ \\
\hline & & 5 & 13 & 2 & 6 \\
\hline & $N=$ & 54 & 54 & 40 & 40 \\
\hline
\end{tabular}

younger brother would increase the likelihood of a girl achieving graduate status, but only if she had no older brothers and no sisters. This finding would agree with studies by Koch (1954) and Schoonover (1959) which indicated that a male sib raises intelligence and achievement scores regardless of the sex of the subject among kindergarten and grade school children. Koch interpreted these findings to mean that the more aggressive and competitive male makes his sib more alert than the passive female. Whether her interpretation is correct is less important than the findings themselves, which would lead one to anticipate that more graduate students would have brothers than sisters regardless of ordinal position. Our findings, on the other hand, indicate that a younger brother only would have a stimulating effect, whereas an older brother would have an inhibiting effect. 
If a male sib raises the score of a five and six year old, on the one hand, and having an older brother is a handicap for a girl wanting to enter medical or dental school on the other, what has happened in the intervening years? The extra potential that existed when these girls entered latency apparently disappeared by the time they chose a career. It could well be that an older male sib is more likely to have used some of the family's resources for a higher education. One might also speculate that families have a certain number of slots, regardless of their financial capabilities, slots for status and success in the world, for having children, for being the rebel in the family, for being conservative, and so on. If the slot for an aggressive pursuit of a career, success and status has already been used by the older brother, there may be an unconscious effort to channel a younger daughter into a less aggressive role, such as marriage and having a family, in order to fill the slot for grandchildren and close family ties. It is also possible that the same older brother who enjoyed competing with his little sister when she was small no longer enjoys the competition after puberty, but penalizes her in subtle ways if she does not give up of her own accord. This interpretation is illustrated by a number of letters from female college students quoted in an article by Komarovski (1946) and included in a more recent work by Bardwick (1972): 
One student writes:

One of my two brothers writes: "Cover up that high forehead and act a little dumb once in a while"; while the other always urges upon me the importance of rigorous scholarship.

Another student recollects:

I could match my older brother in skating, sledding, riflery, ball, and many of the other games we played. He enjoyed teaching me and took great pride in my accomplishments. Then one day it all changed. He must have suddenly- become conscious of the fact the girls ought to be feminine. I was walking with him proud to be able to make long strides and keep up with his long legged steps when he turned to me in annoyance, "Can't you walk like a lady?" I still remember feeling hurt and bewildered by his scorn, when I had been led to expect approval.

Another student wrote to her brother after a date:

"What a beautiful evening at ---- fraternity house! You would be proud of me, Johnny, I won all pingpong games but one!"

"For heaven's sake", came the reply, "when will you grow up? Don't you know that a boy likes to think he is better than a girl? Give him a little competition, sure, but miss a few serves in the end. Should you join the Debate Club? By all means, but don't practice too much on the boys.". Believe me I was stunned by this letter, but then I saw that he was right. To be a success in the dorms one must date, to date one must not win too many ping-pong games. At first I resented this bitterly. But now $I$ am more or less used to it and live in hope of one day meeting a man who is my superior so that I may be my natural self.

The implication that she is not feminine enough, that his male friends don't like her, that she is too pushy and so on is hard to take for a young girl who is not yet grown enough to feel sure of her femininity regardless of what the older boys say. She may find herself doing less well in school now than she used to, and not know herself 
the reason why.

To sum up, our findings would indicate that having an older brother in some way inhibits a girl from entering a profession, and that this trend is more apparent in the higher status mical-dental profession than in social work. This appears to be true whether individuals having older brothers only are counted, or individuals having older brothers who may also have siblings in other categories. On the other hand, having younger brothers among other siblings seems to make no difference. Only when individuals are counted who have younger brothers only does a trend appear, and the trend is opposite of that for older brothers. Taken together with the findings of Koch and Schoonover, which would lead one to expect that having a brother, either older or younger, should be an advantage, we may conclude that there is an opposite trend at work in the case of older brothers. This opposite trend must take its effect during late childhood and adolescence.

III. A COMPARISON BETWEEN MALE AND FEMALE STUDENTS WITH REGARD TO ORDINAL POSITION

The most striking correlation in our findings can be seen in Table I, a portion of which is reproduced on page 35 . Older siblings of both sexes are counted, and it becomes apparent that significantly fewer female 
students have older siblings than male students. A comparison with Table III, which shows only children in the bottom row, indicates that there is no significant difference between male and female students in that regard, so what is seen on Table I (and excerpt below) as students without older siblings is predominantly oldest children, not only children. A closer look at the oldest child who is a female is therefore indicated.

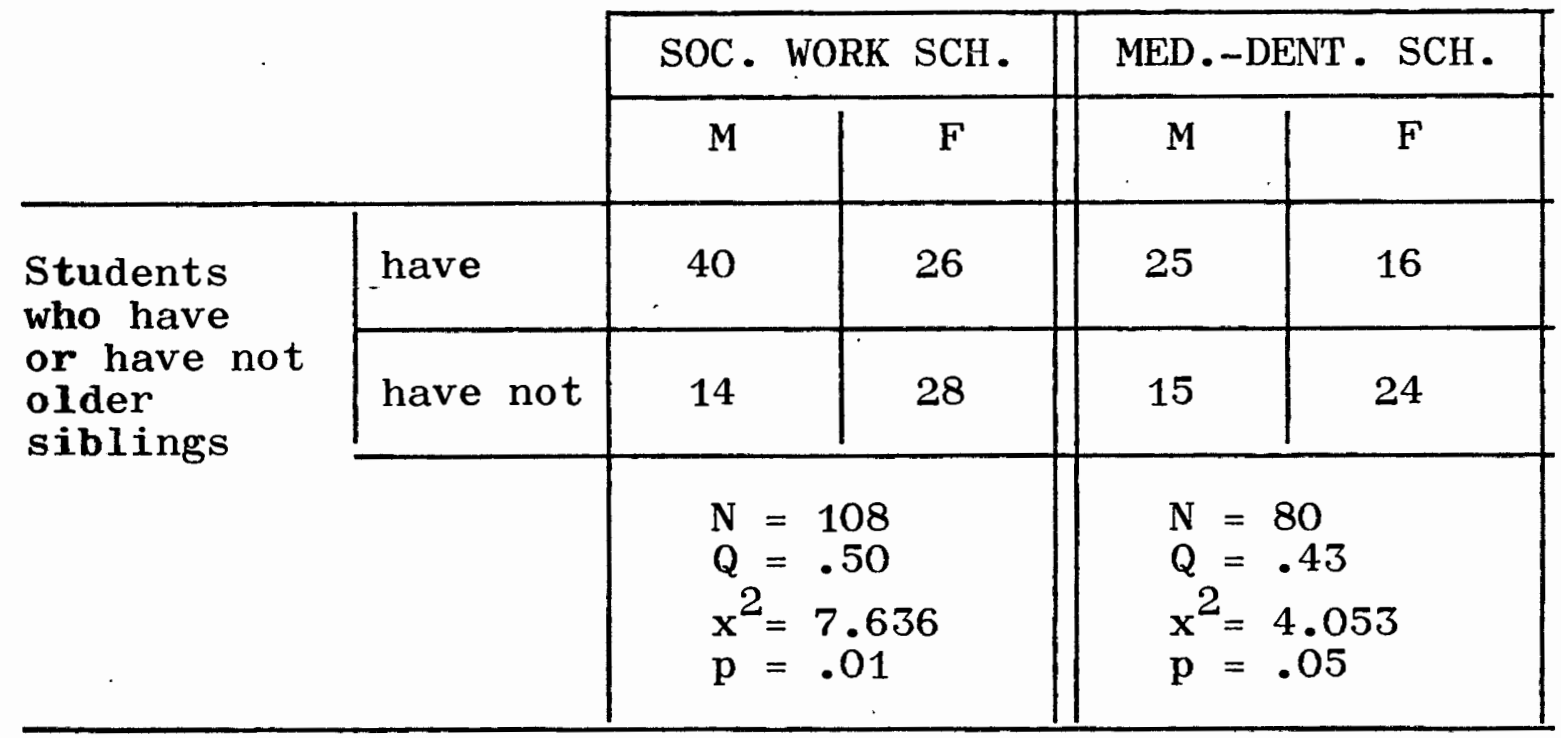

We have already had a glimpse of her as the FF and FM who were characterized as enthusiastic, competitive, aggressive, high on jealousy, and so on. All these characteristics are consistent with this girl being later a candidate for graduate school, but we still do not know anything of the dynamics within the family which have produced these attributes.

oldest daughters, more often than oldest sons, are used as parent surrogates. They are asked to assume more 
responsibility for younger sibs at an early age. If this was the only significant influence we should expect her to be so duty conscious as not to want to pursue a career, but stay home and help mother, or to model herself after her mother and raise a family of her own. Something else must be at work her to give the oldest daughter the confidence and aggressiveness that would allow her to enter a competitive profession.

This girl was once an only child, for a period of time. So, of course, was the oldest child who is a male. What, then, is different about being an oldest male child from being an oldest female child? Could it be that for a female child the competition of the younger children is more threatening, that she is less secure in her place? Could it be that she reacts to this pressure from the younger children by remaining on her toes, by resolving somewhere along the line that she will remain on top, exceptional, outstanding, no matter what? Or is it possible that this oldest daughter, who was drafted into the position of mother's helper without the satisfaction of being the mother herself, has decided at an early age that this role is not primarily the one she wants? Housework and caring for children may be very satisfying to the housewife and mother, but rarely to the older sibling who lacks the maturity and perspective to see potential for satisfaction in these "chores".

These are speculations, but somewhere within the 
politics of each family a struggle occurs, and all we know is that a daughter who is an oldest child is more likely than a younger sister to compete for a place in a male dominated society. 


\section{CHAPTER V}

\section{IMPLICATIONS FOR SOCIAL WORK PRACTICE}

Sibling research is important for social work practice because it illuminates particular aspects of personality development. The social worker specializing in counseling is well aware of the importance of early childhood environment, but while the importance of parental influence has long been recognized, the particular pressures of the sibling community haveooften been neglected.

This community exerts its influence on the growing child in a number of ways. The small person's self-perception is a delicate combination of his environment on the one hand, and the opinion of that environment of him, as he. perceives it, on the other. Growing up in a circle of siblings is somewhat like living in a chamber of mirrors: feedback is continuous, and not necessarily complimentary. Whether this feedback is essentially supportive or destructive varies in each instance, and much more needs to be learned about it.

A large family often divides into groups, where some members are seen as allies, others as enemies. These allegiances may be permanent and stable throughout childhood, or they may be in a state of flux, requiring certain types of behavior from the small person lest he loose his position. The politics of the nursery can be very complex, and probably 
help to develop a certain amount of diplomatic skill.

In the two child family relationships are simpler, but in their very polarity and constancy they may àlso be more damaging and stereotyping. Once the sibling's sensitive spot has been uncovered it tends to be the target over and over again in moments of rage, and self-images of being fat, long-nosed, bow-legged, and so on are firmly entrenched through years of reinforcement during verbal battles. Besides receiving direct feedback from his siblings, the child also learns to measure himself in comparison to them. Thus it is not so much the amount of affection or punishment he receives from his parents, but how much he receives compared to his brothers and sisters which impresses the child. Tom Smother's old line "Mom always loved you best" struck a familiar chord in many listeners, and his brother played the smug part of the sib.who knows that he was indeed the favored one quite recognizably. Measuring our good or bad fortune in comparison to others is not limited to siblings, but is true of any group of children or adults. What is different about siblings is that the contestants are always the same and everpresent in the environment of the growing child. Nor does the child only imagine the comparison with his siblings, but it is very real: parents, grandparents, and teachers frequently and openly compare:siblings to each other.

Whether our tendency to evaluate ourselves by com- 
parison with our peers is an innate human characteristic or a habit acquired through sibling rivalries is difficult to determine, it may well be some of both. Unquestionably, old sibling relationships are often and unconsciously continued in later relationships where they are all the more destructive because they are not understood. Thus a girl who grew up feeling defeated in competition with her brother may continue to feel defeated and enraged by her husband or even her sons, and the counselor who would only look at her relationship to her father for an answer would be looking in vain.

The application of sibling research to social work practice goes beyond individual counseling. The social worker and therapist working with groups is well aware of the fact that the individual's first group experience is usually the sibling environment, and that his relationship to that first environment still influences his behavior within any group. A better understanding of the dynamics of the sibling group is an invaluable tool for any group worker.

Through books and magazines on child rearing new insights filter to the public fairly rapidly. A greater emplwis on siblings, and an understanding particularly of the influence of ordinal position and sibling sex could help to minimize destructive effects. As parents, educators, and college admission boards become more aware of some of 
the handicaps, for instance, of the second and later born daughters, a conscious effort could be made to help these girls overcome that particular disadvantage.

It would be a grave error to conclude that having siblings is a misfortune, it would be as absurd as suggesting that all infants should be removed from their parents because some parents do great damage to their children. The nuclear family is the environment in which most of us in our society have grown up, and from which we have drawn our strengths as well as a few hang-ups. The sibling community is a microcosm of the community at large, and coping in it is essentially a rehearsal for adult life. A better understanding of this microcosm may enable us to minimize its hazards and capitalize on its advantages. 


\section{CHAPTER VI}

\section{SUGGESTIONS FOR FUTURE INQUIRIES}

The influence of sibling sex and ordinal position on sex role learning is a fascinating subject, and the present study is only a small effort to shed some light on it. So far the most impressive work has been done with children (Koch 1954, 1955，1956，1960，1966, Schoonover 1959, SuttonSmith and Rosenberg 1970), but approaching the problem by investigating the sibling status of adults in selected settings seems to us to have some merit, since it gives some insight into what actually happens rather than what is expected to happen to individuals with particular sibling constellations.

Other populations might even be more suitable, particularly an investigation of more sex-role stereotyped groups. Sibling status of students of police and military academies might be compared to student nurses, fashion models, and so on, or male and female athletes might be compared. Another interesting comparison would be between women who are active in women's groups that are primarily supportive of men, such as various auxiliary organizations for wives of men in particular professions, to women who are active in the women's movement itself. We have only scratched the surface of this fascinating field. 


\section{CHAPTER VII}

\section{CONCLUSION}

We have seen that our hypthesis, i.e. that brothers reinforce sex role learning of their sisters, is only partially supported by the evidence. The reinforcing effect appears only in the case of older brothers, and may be due as much to their age as to their sex.

We have found that a significantly greater number of female students are without older siblings than male students. Taken together with the findings of Schooler (1964) that second and later born females are overrepresented in psychiatric wards, one wonders whether the greater aggressiveness and confidence of the older sister is some measure of her more robust mental health. For the counselor and psychotherapist a greater understanding of ordinal position to mental health would be very helpful.

We have discussed in our introduction how sibling sex and ordinal position have affected human lives in our history. Looking toward the future, we can only speculate what effect the trend towards smaller families will have on our social structure. One thing can be anticipated: as families become smaller, a larger proportion of females will be firstborn children. Perhaps this trend to smaller family size will thus contribute to bringing about a more 
equitable distribution of the sexes in high status professions. The diminishing number of second and later borns in the future may contribute to a better mental health outlook for the female population on the whole. Since the preponderance of first-born males will also be on the increase, the: reported similarity of the first-born male to the secondborn female (Sampson 1965) may contribute to a male-female • role reassignment as an incidental result of population control. Unfortunately, there will probably be few researchers who will look for one of the causes of future role changes in charging sibling constellations. 


\section{REFERENCES}

Abernathy, E.M. 1940. "Data on Personality and Family Position", Journal of Psychology, X, 303-307.

Adler, Alfred 1970. Superiority and Social Interest, Northestern University Press.

Bardwick, J.M. (Ed.) 1972. Readings on the Psychology of Women, Harper \& Row, New York.

Bardwick, J.M. and E. Douvan 1971. "Ambivalence: The Socialization of Women," in V. Gornich and B.K. Moran (Eds.) Woman in Sexist Society, Basic Books, Inc., New York. 147-159.

Biller, Henry 1969. "Father ment in Kindergarten Age Boys," in David R. Heise (Ed.) Personality and Socialization, Rand McNally \& Co., Chicago.

Bird, Caroline and Sara W. Briller 1970. Born Female, David McKay Company, Inc. New York.

Comer, N.A. 1974. "From Honey to Ms. to Doctor," Mademoiselle, April 1974, 204.

Comfort, Alex 1966. The Nature of Human Nature, Harper \& Row, New York, 32-33.

Darke, R.A. "Heredity as an Etiological Factor in Homosexuality", Journal of Nervous and Mental Disease, 1948, Vol. 107, 251-268.

DeMause, Lloyd 1974. "The Evolution of Childhood," History of Childhood Quarterly, Vol. 1, No. 4. 503-575.

Deutsch, Helene 1944. The Psychology of Women, Grune \& Stratton, New York.

Grinberg, Leon et al. Psychoanalytische Gruppentherapie, Ernst Klett Verlag, Stuttgart, 1960.

Harrington, Charles C. 1970. Errors in Sex-Role Behavior in Teen-Age Boys, Teachers College Press, Teachers College, Columbia University, New York, 75-76. 
Heise, David R. (Ed.) 1972. Personality and Socialization, Rand McNally \& Co., Chicago.

Kallmann, F. J. 1952. "Comparitive Twin Study on the Genetic Aspects of Homosexuality," Journal of Nervous and Mental Disease, Vol 115, 44-45.

Koch, Helen L. 1954. "The Relation of Primary Mental Abilities in Five and Six Year Olds to Sex of Child and Characteristics of Sibling," Child Development, Vol. 25, 209-223.

Koch, Helen L. 1955. "Some Personality Correlates of Sex, Sibling Position, and Sex of Sibling among Five and Six Year Old Children," Genetic Psychological Monographs, Vol. 52, 3-50.

Koch, Helen L. 1956. "Sissiness and Tomboyishness in Relation to Sibling Characteristics," Journal of Genetic

Psychology, Vol. 88, 231-244.

Koch, Helen L. 1966. Twins and Twin Relations, University of Chicago Press.

Komarovski, Mira 1946. "Cultural Contradictions and Sex Roles," American Journal of Sociology, Vol. 52, No. 3, 184-189. (Also in J.M. Bardwick, . Ed., Readings on the Psychology of Women. New York, Harper \& $\overline{R o w}, 1972)$

Lambert, Ronald 197.1. Sex Role Imagery in Children: Social Origins of Mind. Information Canada, Ottawa.

Lang, T. 1940. "Studies on the Genetic Determination of Homosexuality," Journal of Nervous and Mental Disease, Vol. $92,55-64$.

Martensen-Larsen, O. 1957. "The Family Constellation and Homosexualism", Acta Genetica et Statistica, Vol. 7, $445-446$.

Mattfeld, Jacqueline A. and Carol G. Van Aken (Eds.) 1965. Women and the Scientific Professions, M.I.T. Press, Cambridge, Mass.

Mead, Margaret and Frances Balgley Kaplan (Eds.) 1965. American Women, the Report of the President's Commission on the Status of Women and Other Publications of the Commission, Charles Scribner's Sons, New York.

Money, John 1970. "Sexual Dimorpism and Homosexual Gender Identity, "Psychological Bulletin Vol. 74, No. 6 425-440. (Also in J.M. Bardwick, Ed., Readings on the Psychology of Women, New York, Harper \& Row, 1972) 
Mussen, Pau. H. 1969. "Early Sex Role Development," from David R. Goslin (Ed.) Handbook of Socialization Theory and Research, Rand McNally, Chicaso.

National Education Association, (Ed.) 1973. Sex Róle Stereotyping in the Schools. N.E.A. of the U.S.

Oakley, Ann 1972. Sex, Gender, and Society, Morris Temple Smith, Ltd., London, 173-177.

Pincus, Cynthia, Natalie Radding and Roberta Lawrence 1974. "A Professional Counseling Service for Women", Social Work; Vol. 19, No. 2, 187-195.

Porteous;, .Hedy S. 1972. Sex and Edentity,, Bobbs-Merris Co., Indianapolis, New York.

Rossi, Alice S. 1965. "Barriers to the Career Choice of Engineering, Medicine or Science among American Women, " in J. Mattfeld and C. Van Aken (Eds.) Women and the Scientific Professions, M.I.T. Press, Cambridge, Mass. 51-127.

Rothbart, Mary K. and Eleanor E. Maccoby 1966. "Parents' Differential Reactions to Sons and Daughters," in Mussen et al. (Eds.) Readings in Child Development and Personality, Harper \& Row, New York.

Roszak, Betty and Thodore Roszak (Eds.) 1969. Masculine/Feminine, Harper Colophon Books, Harper \& Row, New York.

Sampson, Edward E. 1962. "Birth Order, Need Achievement, and Conformity," Journal of Abnormal Social Psychology Vol. 64, 155-159.

Sampson, Edward E. 1965. "The Study of Ordinal Position: Antecedents and Outcome," from Brendan E. Maher (Ed.) Progress in Experimental Personality Research Vol. 2, Academic Press, New York, 175-228. Also in David R. Heise (Ed.) Personality and Socialization, Rand McNally, Chicago, 1972, 86-117.

Savioz, Esther 1968. Die Anfange der Geschwisterbeziehung, Huber, Bern und Stuttgart.

Schachter, S. 1963. "Birth Order, Eminence, and Higher Education," American Sociological Review, Vol 28, 757-776.

Scheinfeld, A. 1967. Twins and Supertwins, Philadelphia Lippincott. 
Schmuck, R. 1963. "Sex of Sibling, Birth Order Position, and Female Disposition to Conformity in Two-Child Families", Child Development, Vol. 34, 913-18.

Schooler, C. 1964. "Birth Order and Hospitalization for Schizophrenia," Journal of Abnormal and Social Psych. Vol. 69, 574-579.

Schoonover, Sarah. 1953. "A Longitudinal Study of Sibling Resemblances in Intelligence and Achievement," Journal of Educational Psychology, Vol. 39, 436-442.

Schoonover, Sarah. 1959. "The Rela tionship of Intelligence and Achievement to Birth Order, Sex of Sibling, and Age Interval," Journal of Educational Psychology, Vol. 50 143-146.

Schwartz, Mary C. 1974. "Importance of Sex of Worker and Client," Social Work, Vol. 19, No. 2, 177-185.

Sears, Pauline 1951. "Doll Play Aggression in Normal Young

- Children: Influence of Sex, Age, Sibling Status, Father's Absence," Psychological Monographs, Vo1. 65, No. 6 .

Sears, Robert R., : Lucy Rau and. Richard Alpert 1965, Identification and Child Rearing, Stanford University Press; Stanford, Calif.

Singer, J.E. 1964. "The Use of Manipulative Strategies: Machiavellianism and Attractiveness," Sociometry, Vol. 27, 128-150.

Slater, E. 1962. "Birth Order and Maternal Age of Homosexuals", Lancet, Vol. 1, 69-71.

Sutton-Smith, Brian and B.G. Rosenber 1970, The Sibling, Holt, Rinehart and Winston, Inc. New York.

Toman, Walter 1969. Family Constellation, its Effects on Personality and Social Behavior, Springer Publishing Co., New York. 


\section{APPENDIX A}

TABLES I THROUGH XII 
TABLE I

NUMBER OF MALE OR FEMALE STUDENTS WHO HAVE OLDER SIBLING(S)

Students who have or have not siblings up to two years older

Students who. have or have not siblings up to four years older

\begin{tabular}{|c|c|c|c|c|}
\hline & \multicolumn{2}{|c|}{ SOC. WORK SCH. } & \multicolumn{2}{|c|}{ MED.-DENT . SCH } \\
\hline & M & $\mathbf{F}$ & $\mathbf{M}$ & $\mathbf{F}$ \\
\hline have & 15 & 8 & 12 & 9 \\
\hline \multirow[t]{2}{*}{ have not } & 39 & 46 & 28 & 31 \\
\hline & \multicolumn{2}{|c|}{$\begin{array}{l}\mathrm{N}=108 \\
\mathbf{Q}=.37 \\
\mathbf{x}^{2}=2,706\end{array}$} & \multicolumn{2}{|c|}{$\begin{array}{l}N=80 \\
Q=.19 \\
x^{2}=0.581\end{array}$} \\
\hline have & 26 & 18 & 19 & 12 \\
\hline \multirow[t]{2}{*}{ have not } & 28 & 36 & 21 & 28 \\
\hline & \multicolumn{2}{|c|}{$\begin{array}{l}N=108 \\
Q=.30 \\
x^{2}=2.504\end{array}$} & \multicolumn{2}{|c|}{$\begin{aligned} \mathbf{N} & =80 \\
\mathbf{Q} & =.35 \\
\mathbf{x}^{2} & =2.580\end{aligned}$} \\
\hline have & 28 & 21 & 22 & 16 \\
\hline \multirow[t]{2}{*}{ have not } & 26 & 33 & 18 & 24 \\
\hline & \multicolumn{2}{|c|}{$\begin{array}{l}\mathrm{N}=108 \\
\mathrm{Q}=.25 \\
\mathbf{x}^{2}=1.830\end{array}$} & \multicolumn{2}{|c|}{$\begin{array}{l}N=80 \\
Q=.26 \\
x^{2}=1.804\end{array}$} \\
\hline have & 40 & 26 & 25 & 16 \\
\hline \multirow[t]{2}{*}{ have not } & 14 & 28 & 15 & 24 \\
\hline & \multicolumn{2}{|c|}{$\begin{array}{l}N=108 \\
Q=.50\end{array}$} & \multicolumn{2}{|c|}{$\begin{array}{l}N=80 \\
Q=43\end{array}$} \\
\hline
\end{tabular}

Students who have or have not siblings up to six years older

Students who have or have not older siblings without age limit 
TABLE II

NUMBER OF MALE OR FEMALE STUDENTS WHO HAVE YOUNGER SIBLING(S)

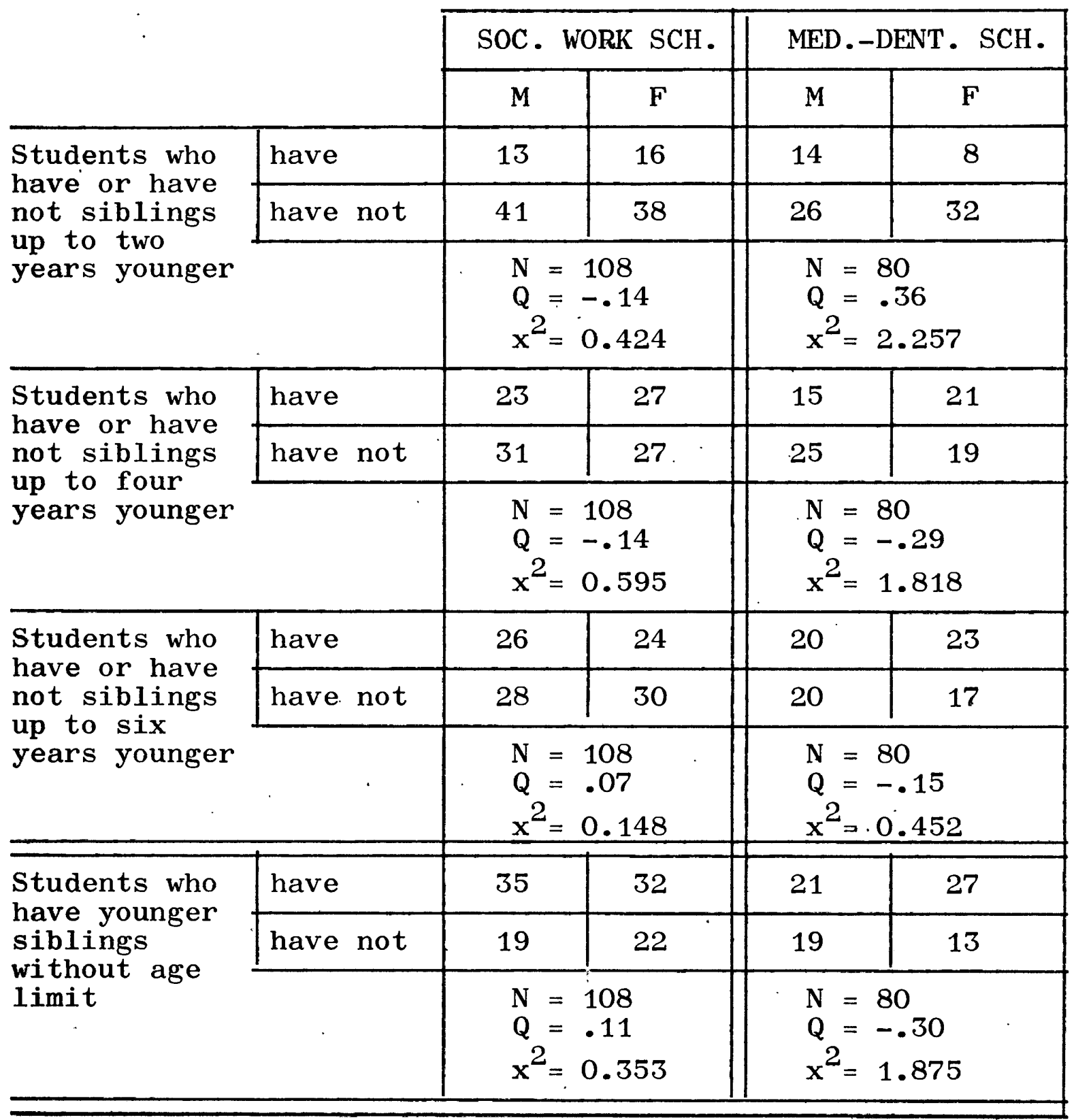


TABLE III

NUMBER OF MALE OR FEMALE STUDENTS WHO HAVE SIBLING(S)

\begin{tabular}{|c|c|c|c|c|c|}
\hline & \multicolumn{2}{|c|}{ SOC. WORK SCH. } & \multicolumn{2}{|c|}{ MED . -DENT - SCH . } \\
\hline & & $\mathbf{M}$ & $\mathbf{F}$ & M & $\mathbf{F}$ \\
\hline \multirow{3}{*}{$\begin{array}{l}\text { Students who } \\
\text { have or } \\
\text { have not } \\
\text { siblings up } \\
\text { to two years } \\
\text { older or up } \\
\text { to two years } \\
\text { younger }\end{array}$} & have & 22 & 19 & 18 & 14 \\
\hline & have not & 32 & 35 & 22 & 26 \\
\hline & & $\begin{array}{l}\mathbf{N} \\
\mathbf{Q} \\
\mathbf{x}^{2}\end{array}$ & & $\begin{array}{l}\mathbf{N} \\
\mathbf{Q} \\
\mathbf{x}^{2}\end{array}$ & \\
\hline \multirow{3}{*}{$\begin{array}{l}\text { Students who } \\
\text { have or } \\
\text { have not } \\
\text { siblings up } \\
\text { to four years } \\
\text { older or up } \\
\text { to four years } \\
\text { younger }\end{array}$} & have & 37 & 35 & 31 & 27 \\
\hline & have not & 17 & 19 & 19 & 13 \\
\hline & & & & $\begin{array}{l}\mathbf{N} \\
\mathbf{Q} \\
\mathbf{x}^{2}\end{array}$ & \\
\hline \multirow{3}{*}{$\begin{array}{l}\text { Students who } \\
\text { have or } \\
\text { have not } \\
\text { siblings up } \\
\text { to six years } \\
\text { older or up } \\
\text { to six years } \\
\text { younger }\end{array}$} & have & 44 & 44 & 37 & 30 \\
\hline & have not & 10 & 10 & 3 & 10 \\
\hline & & & & $\begin{array}{l}\mathbf{N} \\
\mathbf{Q} \\
\mathbf{x}^{2}\end{array}$ & $500^{* *}$ \\
\hline \multirow{3}{*}{$\begin{array}{l}\text { Students who } \\
\text { have or } \\
\text { have not } \\
\text { older or } \\
\text { younger sib- } \\
\text { lings with- } \\
\text { out age } \\
\text { limit }\end{array}$} & have & 51 & 48 & 40 & 37 \\
\hline & have not & 3 & 6 & $\mathrm{O}$ & 3 \\
\hline & & & $\begin{array}{l}8 \\
6 \\
090\end{array}$ & $\begin{array}{l}N \\
Q \\
x^{2}\end{array}$ & $116^{*}$ \\
\hline
\end{tabular}

* Significant at 0.10

** Significant at 0.05 
TABLE IV

NUMBER OF MALE OR FEMALE STUDENTS HAVING

OLDER SAME SEX SIBLING(S)

\begin{tabular}{|c|c|c|c|c|c|}
\hline \multirow{2}{*}{\multicolumn{2}{|c|}{ ' }} & \multicolumn{2}{|c|}{ SOC. WORK SCH. } & \multicolumn{2}{|c|}{ MED. - DENT . SCH } \\
\hline & & $\mathbf{M}$ & $F$ & $\mathbf{M}$ & $F$ \\
\hline \multirow{3}{*}{$\begin{array}{l}\text { Students who } \\
\text { have or } \\
\text { have not } \\
\text { same sex } \\
\text { siblings } \\
\text { up to two } \\
\text { years } \\
\text { older }\end{array}$} & have & 8 & 4 & 7 & 5 \\
\hline & have not & 46 & 50 & 33 & 35 \\
\hline & & \multicolumn{2}{|c|}{$\begin{array}{l}\mathrm{N}=108 \\
\mathrm{Q}=.36 \\
\mathrm{x}^{2}=1.500\end{array}$} & \multicolumn{2}{|c|}{$\begin{array}{l}N=80 \\
Q=.19 \\
\mathbf{x}^{2}=0.392\end{array}$} \\
\hline \multirow{2}{*}{$\begin{array}{l}\text { Students who } \\
\text { have or } \\
\text { have not }\end{array}$} & have & 13 & 8 & 13 & 8 \\
\hline & have not & 41 & 46 & 27 & 32 \\
\hline \multicolumn{2}{|l|}{$\begin{array}{l}\text { same sex } \\
\text { siblings } \\
\text { up to four } \\
\text { years } \\
\text { older }\end{array}$} & \multicolumn{2}{|c|}{$\begin{array}{l}N=108 \\
Q=.29 \\
x^{2}=1.477\end{array}$} & \multicolumn{2}{|c|}{$\begin{array}{l}N=80 \\
Q=.31 \\
x^{2}=1.614\end{array}$} \\
\hline \multirow{3}{*}{$\begin{array}{l}\text { Students who } \\
\text { have or } \\
\text { have not } \\
\text { same sex } \\
\text { siblings } \\
\text { up to six } \\
\text { years } \\
\text { older }\end{array}$} & have & 18 & 11 & 13 & 9 \\
\hline & have not & 36 & 43 & 27 & 31 \\
\hline & & \multicolumn{2}{|c|}{$\begin{array}{l}N=108 \\
Q=.26 \\
x^{2}=1.508\end{array}$} & \multicolumn{2}{|c|}{$\begin{array}{l}N=80 \\
Q=.23 \\
x^{2}=1.003\end{array}$} \\
\hline \multirow{3}{*}{$\begin{array}{l}\text { Students who } \\
\text { have or } \\
\text { have not } \\
\text { older same } \\
\text { sex sib- } \\
\text { lings } \\
\text { without age } \\
\text { limit }\end{array}$} & have & 21 & 18 & 16 & 12 \\
\hline & have not & 33 & 36 & 24 & 28 \\
\hline & & \multicolumn{2}{|c|}{$\begin{array}{l}N=108 \\
Q=.12 \\
\mathbf{x}^{2}=0.361\end{array}$} & \multicolumn{2}{|c|}{$\begin{array}{l}N=80 \\
Q=.21 \\
x^{2}=0.879\end{array}$} \\
\hline
\end{tabular}


TABLE V

NUMBER OF MALE OR FEMALE STUDENTS WHO

HAVE YOUNGER SAME SEX SIBLING(S)

\begin{tabular}{|c|c|c|c|c|c|}
\hline & & \multicolumn{2}{|c|}{ SOC. WORK SCH. } & \multicolumn{2}{|c|}{ MED.-DENT . SCH . } \\
\hline & & $\mathbf{M}$ & $\mathbf{F}$ & $\mathbf{M}$ & $\mathbf{F}$ \\
\hline \multirow{3}{*}{$\begin{array}{l}\text { Students who } \\
\text { have or } \\
\text { have not } \\
\text { same sex } \\
\text { siblings } \\
\text { up to two } \\
\text { years } \\
\text { younger }\end{array}$} & have & 6 & 4 & 7 & 5 \\
\hline & have not & 48 & 50 & 33 & 35 \\
\hline & . & \multicolumn{2}{|c|}{$\begin{array}{l}N=108 \\
Q=.20 \\
x^{2}=0.440\end{array}$} & \multicolumn{2}{|c|}{$\begin{array}{l}N=80 \\
Q=.19 \\
\dot{x}^{2}=0.394\end{array}$} \\
\hline \multirow{3}{*}{$\begin{array}{l}\text { Students who } \\
\text { have or } \\
\text { have not } \\
\text { same sex } \\
\text { siblings } \\
\text { up to four } \\
\text { years } \\
\text { younger }\end{array}$} & have & 14 & 12 & 11 & 13 \\
\hline & have not & 40 & 42 & 29 & 27 \\
\hline & . & \multicolumn{2}{|c|}{$\begin{array}{l}N=108 \\
Q=\cdot 10 \\
\mathbf{x}^{2}=0.202\end{array}$} & \multicolumn{2}{|c|}{$\begin{array}{l}\mathrm{N}=80 \\
\mathrm{Q}=-.11 \\
\mathbf{x}^{2}=0.238\end{array}$} \\
\hline \multirow{3}{*}{$\begin{array}{l}\text { Students who } \\
\text { have or } \\
\text { have not } \\
\text { same sex } \\
\text { siblings } \\
\text { up to six } \\
\text { years } \\
\text { younger }\end{array}$} & have & 17 & 13 & 12 & 15 \\
\hline & have not & 37 & 41 & 28 & 25 \\
\hline & & \multicolumn{2}{|c|}{$\begin{array}{l}\mathrm{N}=108 \\
\mathrm{Q}=.18 \\
\mathbf{x}^{2}=0.738\end{array}$} & \multicolumn{2}{|c|}{$\begin{array}{l}N=80 \\
Q=-.16 \\
\mathbf{x}^{2}=0.503\end{array}$} \\
\hline \multirow{3}{*}{$\begin{array}{l}\text { Students who } \\
\text { have or } \\
\text { have not } \\
\text { younger } \\
\text { same sex } \\
\text { siblings } \\
\text { without } \\
\text { age limit }\end{array}$} & have & 23 & 16 & 19 & 19 \\
\hline & have not & 31 & 38 & 21 & 21 \\
\hline & & \multicolumn{2}{|c|}{$\begin{array}{l}N=108 \\
Q=.27 \\
x^{2}=1.966\end{array}$} & \multicolumn{2}{|c|}{$\begin{array}{l}N=80 \\
Q=0 \\
x^{2}=0\end{array}$} \\
\hline
\end{tabular}


TABLE VI

NUMBER OF MALE OR FEMALE STUDENTS WHO HAVE OLDER

OR YOUNGER SAME SEX SIBLING(S)

\begin{tabular}{|c|c|c|c|c|c|}
\hline & & \multicolumn{2}{|c|}{ SOC. WORK SCH. } & \multicolumn{2}{|c|}{ MED.-DENT . SCH } \\
\hline & & $\mathbf{M}$ & $\mathbf{F}$ & M & $\mathrm{F}$ \\
\hline \multirow{3}{*}{$\begin{array}{l}\text { Students who } \\
\text { have or } \\
\text { have not } \\
\text { same sex } \\
\text { siblings up to } \\
\text { two years olde } \\
\text { or up to two } \\
\text { years younger }\end{array}$} & have & 12 & 8 & 13 & 9 \\
\hline & have not & 42 & 46 & 27 & 31 \\
\hline & & & & $\begin{array}{l}\mathrm{N} \\
\mathrm{Q} \\
\mathrm{x}^{2}\end{array}$ & \\
\hline \multirow{2}{*}{$\begin{array}{l}\text { Students who } \\
\text { have or } \\
\text { have not }\end{array}$} & have & 22 & 20 & 22 & 20 \\
\hline & have not & 32 & 34 & 18 & 20 \\
\hline \multicolumn{2}{|c|}{$\begin{array}{l}\text { siblings up to } \\
\text { four years older } \\
\text { or up to four } \\
\text { years younger. }\end{array}$} & \multicolumn{2}{|c|}{$\begin{array}{l}N=108 \\
Q=.07 \\
x^{2}=0.155\end{array}$} & \multicolumn{2}{|c|}{$\begin{array}{l}N=80 \\
Q=.08 \\
x^{2}=0.200\end{array}$} \\
\hline \multirow{3}{*}{$\begin{array}{l}\text { Students who } \\
\text { have or } \\
\text { have not } \\
\text { same sex } \\
\text { siblings up to } \\
\text { six years olde } \\
\text { or up to six } \\
\text { years younger }\end{array}$} & have & 28 & 22 & 23 & 22 \\
\hline & have not & 26 & 32 & 17 & 18 \\
\hline & & & 340 & & \\
\hline \multirow{3}{*}{$\begin{array}{l}\text { Students who } \\
\text { have or } \\
\text { have not } \\
\text { older or } \\
\text { younger same } \\
\text { sex siblings } \\
\text { without age } \\
\text { limit }\end{array}$} & have & 35 & 32 & 30 & 27 \\
\hline & have not & 19 & 22 & 10 & 13 \\
\hline & & & $\begin{array}{l}3 \\
1 \\
353\end{array}$ & & \\
\hline
\end{tabular}


TABLE VII

NUMBER OF MALE OR FEMALE STUDENTS WHO HAVE

OLDER OPPOSITE SEX SIBLING(S)

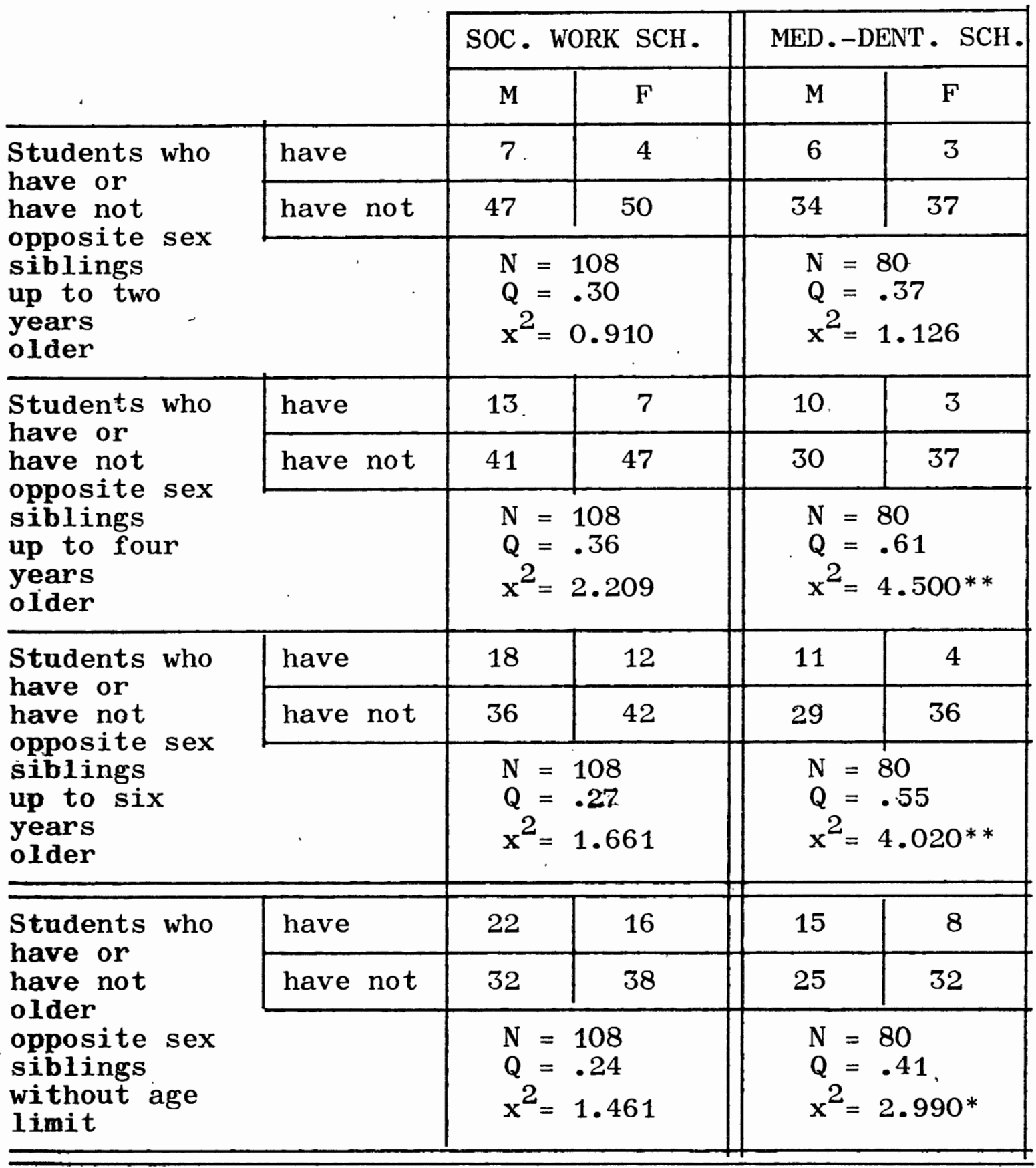


TABLE VIII

NUMBER OF MALE OR FEMALE STUDENTS WHO HAVE

YOUNGER OPPOSITE SEX SIBLING(S)

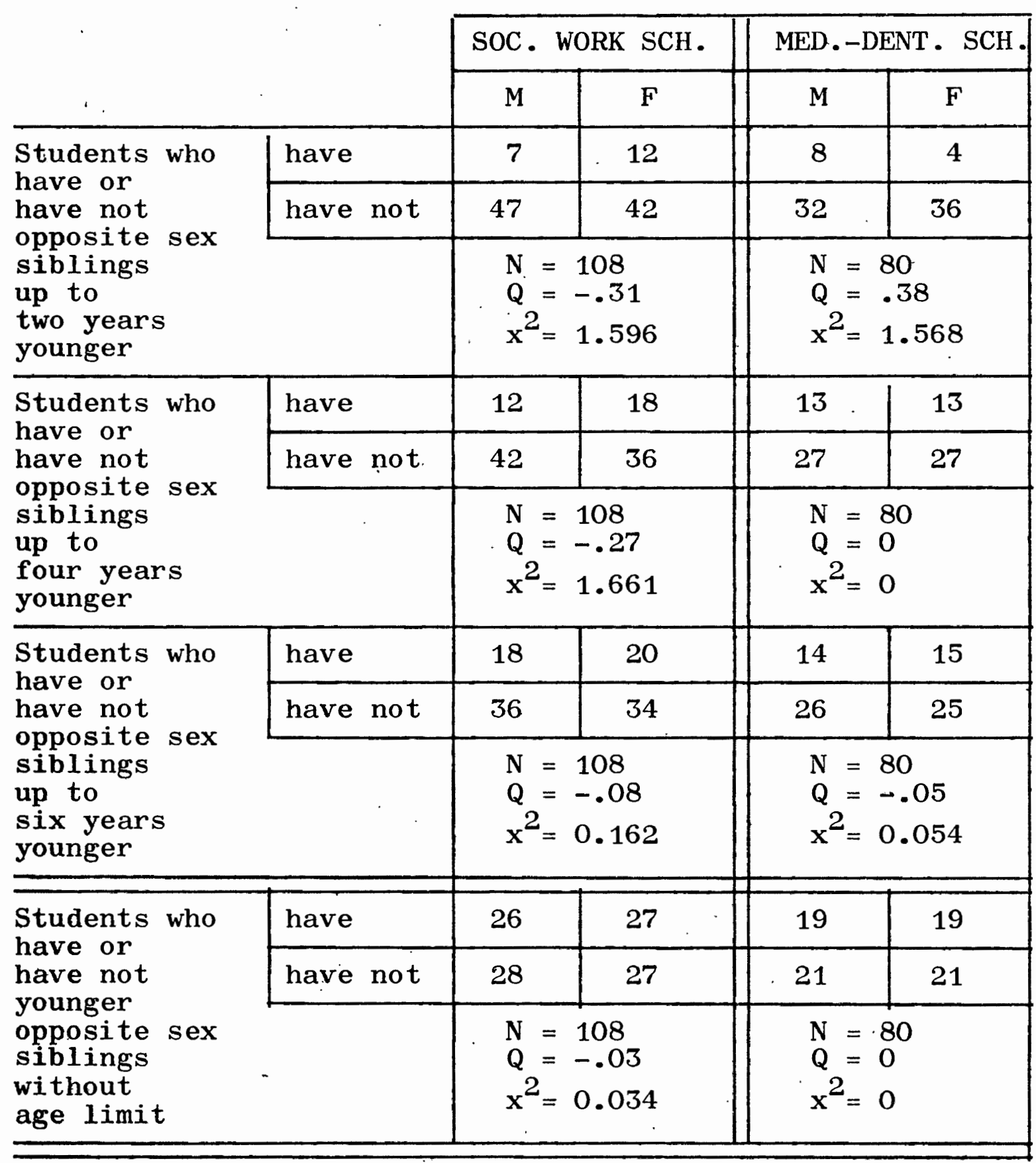


TABLE IX

NUMBER OF MALE OR FEMALE STUDENTS WHO HAVE OLDER OR YOUNGER OPPOSITE SEX SIBLING(S)

\begin{tabular}{|c|c|c|c|c|c|}
\hline & & SOC. & K SCH. & MED . & T. \\
\hline & & M & $\mathrm{F}$ & $\mathbf{M}$ & $\mathrm{F}$ \\
\hline Students who & have & 12 & 15 & 13 & 7 \\
\hline have not & have not & 42 & 39 & 27 & 33 \\
\hline $\begin{array}{l}\text { siblings up to } \\
\text { two years olde } \\
\text { or up to two } \\
\text { years younger }\end{array}$ & & $\begin{array}{l}\mathrm{N} \\
\mathrm{Q} \\
\mathbf{x}^{2}\end{array}$ & $\begin{array}{l}8 \\
14 \\
444\end{array}$ & & \\
\hline Students who & have & 21 & 24 & 20 & 16 \\
\hline have not & have not & 33 & 30 & 20 & 24 \\
\hline $\begin{array}{l}\text { siblings up to } \\
\text { fou years olde } \\
\text { or up to four } \\
\text { years younger. }\end{array}$ & & & $\begin{array}{l}8 \\
11 \\
342\end{array}$ & & \\
\hline Students who & have & 29 & 29 & 21 & 19 \\
\hline have not & have not & 25 & 25 & 19 & 21 \\
\hline $\begin{array}{l}\text { siblings up to } \\
\text { six years olde } \\
\text { or up to six } \\
\text { years younger }\end{array}$ & . & & & & \\
\hline Students who & have & 41 & 41 & 30 & 24 \\
\hline have not & have not & 13 & 13 & 10 & 16 \\
\hline $\begin{array}{l}\text { younger } \\
\text { opposite sex } \\
\text { siblings with- } \\
\text { out age limit }\end{array}$ & & & & & \\
\hline
\end{tabular}




\section{TABLE X}

NUMBER OF MALE OR FEMALE STUDENTS WHO HAVE

OLDER OR YOUNGER BROTHERS OR SISTERS

Note: This tabie does not exclude students who may also have siblings in other categories.

\begin{tabular}{l|c|c||c|c|}
\cline { 2 - 5 } & \multicolumn{2}{c|}{ SOC. WORK SCH. } & \multicolumn{2}{c|}{ MED.-DENT. SCH. } \\
\cline { 2 - 5 } & $\mathrm{M}$ & $\mathrm{F}$ & $\mathrm{M}$ & $\mathrm{F}$ \\
\hline Have older brothers* & 21 & 16 & 16 & 8 \\
\hline Have older sisters* & 22 & 18 & 15 & 12 \\
\hline Have older siblings* & 40 & 26 & 25 & 16 \\
\hline Have no older siblings* & 14 & 28 & 15 & 24 \\
\hline Have younger brothers* & 23 & 27 & 19 & 19 \\
\hline Have younger sisters* & 26 & 16 & 19 & 19 \\
\hline Have younger siblings* & 35 & 32 & 21 & 27 \\
\hline Have no younger siblings* & 35 & 22 & 19 & 13 \\
\hline \multicolumn{2}{c}{$\mathrm{N}=54$} & 54 & 40 & 40 \\
\hline
\end{tabular}


TABLE XI

TOTAL NUMBER OF OLDER OR YOUNGER BROTHERS OR SISTERS IN THE FAMILIES OF MALE OR FEMALE STUDENTS IN OUR SAMPLE

\begin{tabular}{c|c|c|c|c|}
\cline { 2 - 5 } & \multicolumn{2}{c|}{ SOC. WORK SCH. } & \multicolumn{2}{c|}{ MED.-DENT. SCH. } \\
\cline { 2 - 5 } & $\mathrm{M}$ & $\mathrm{F}$ & $\mathrm{M}$ & $\mathrm{F}$ \\
\hline Older brothers* & 28 & 27 & 18 & 11 \\
\hline Older sisters* & 26 & 22 & 18 & 14 \\
\hline Younger brothers* & 26 & 37 & 24 & 26 \\
\hline Younger sisters* & 42 & 25 & 24 & 27 \\
\hline \multirow{2}{*}{$\mathrm{N}$} & 54 & 54 & 40 \\
*No upper or lower age limit
\end{tabular}




\section{TABLE XII}

NUMBER OF MALE OR FEMALE STUDENTS WHO HAVE

\section{SIBLINGS IN ONE CATEGORY ONLY}

Note: Categories are mutuaily exclusive. Each student appears only once in category for his or her sibling constellation. Siblings more than 10 years older or more than 10 years younger are not included in this table.

\begin{tabular}{|c|c|c|c|c|}
\hline \multirow[b]{2}{*}{ STUDENTS WHO HAVE ONLY } & \multicolumn{2}{|c|}{ SOC.W.SCH. } & \multicolumn{2}{|c|}{ MD. -DNT . SCH. } \\
\hline & $\mathbf{M}$ & $\mathrm{F}$ & M & $\mathrm{F}$ \\
\hline Older brothers & 5 & 5 & 7 & 1 \\
\hline Older sisters & 8 & 4 & 5 & 5 \\
\hline Older brothers and older sisters & 3 & $\overline{2}$ & $\overline{2}$ & 1 \\
\hline Younger brothers & 5 & 13 & 2 & 6 \\
\hline Younger sisters & 5 & 6 & 7 & 7 \\
\hline $\begin{array}{l}\text { Younger brothers and younger } \\
\text { sisters }\end{array}$ & 3 & 4 & 5 & 7 \\
\hline $\begin{array}{l}\text { Younger brothers and older } \\
\text { brothers }\end{array}$ & 2 & 3 & 3 & 0 \\
\hline $\begin{array}{l}\text { Younger sisters and older } \\
\text { sisters }\end{array}$ & 5 & 0 & 1 & 0 \\
\hline $\begin{array}{l}\text { Older brothers and } \\
\text { younger sisters }\end{array}$ & 3 & 0 & 1 & 2 \\
\hline $\begin{array}{l}\text { Older sisters and } \\
\text { younger brothers }\end{array}$ & 2 & 4 & 3 & 1 \\
\hline $\begin{array}{l}\text { Order brothers and younger } \\
\text { brothers and sisters }\end{array}$ & 5 & 1 & 0 & 1 \\
\hline $\begin{array}{l}\text { Older sisters and younger } \\
\text { brothers and sisters }\end{array}$ & 1 & 0 & 0 & 1 \\
\hline $\begin{array}{l}\text { Younger brothers and older } \\
\text { brothers and sisters }\end{array}$ & 2 & 1 & 1 & 1 \\
\hline $\begin{array}{l}\text { Younger sisters and older } \\
\text { brothers and sisters }\end{array}$ & 0 & 0 & 2 & 2 \\
\hline $\begin{array}{l}\text { 0lder brothers and sisters and } \\
\text { younger brothers and sisters }\end{array}$ & 0 & 1 & 0 & 0 \\
\hline $\begin{array}{l}\text { No brothers and no sisters } \\
\text { (only children) }\end{array}$ & 5. & 10 & 1 & 5 \\
\hline $\mathrm{N}=$ & 54 & 54 & 40 & 40 \\
\hline
\end{tabular}




\section{APPENDIX B}

\section{QUESTIONNAIRE DISTRIBUTED TO STUDENTS AT THE \\ MEDICAL SCHOOL, DENTAL SCHOOL, AND \\ SCHOOL OF SOCIAL WORK}

For my master's thesis in social work I am studying the relationship of sibling status to choice of profession. I am particularly interested in finding out whether female students in high status professions tend to have fewer, more, or the same number of opposite sex sibs as their male colleagues.

Your answers to the following questions would be much appreciated.

Your age:___ yrs.

Your sex: $F \quad M \quad$ (circle one)

Number of living brothers: , living sisters:

Ages of living brothers: '_yrs.

Number of living sisters: ' ',yrs.

If any of your siblings acre deceased, please indicate sex of sib, age at time of death, and year of death

Questions or comments:

Thank you very much for your help.

Anita Witt School of Social Work Portland State University 